\title{
THE BENEFICIAL EFFECTS OF ROSMARINIC ACID ON A NON-TUMORIGENIC EPITHELIAL CELL LINE
}

\author{
Judit M. Pomothy ${ }^{1 *}$, Réka F. Barna ${ }^{1}$, Áron Szóládi ${ }^{1}$ and Erzsébet Pásztiné-Gere ${ }^{1}$ \\ ${ }^{1}$ Department of Pharmacology and Toxicology, University of Veterinary Medicine Budapest, Hungary \\ https://doi.org/10.47833/2020.1.AGR.019
}

\author{
Keywords: \\ IPEC-J2 cell line \\ Rosmarinic acid \\ Cell viability \\ Transepithelial electrical \\ resistance \\ Extracellular $\mathrm{H}_{2} \mathrm{O}_{2}$
}

Article history:

Received 25 Oct 2019

Revised 11 Nov 2019

Accepted 17 Nov 2019

\begin{abstract}
The aim of this study was to investigate the effects of rosmarinic acid (RA) on a porcine, non-tumorigenic IPEC-J2 enterocyte cell line. The cell viability was tested with MTS assay and the transepithelial electrical resistance (TER) values were measured to determine the changes of the membrane integrity. The extracellular $\mathrm{H}_{2} \mathrm{O}_{2}$ production was analyzed with Amplex Red assay. The results show that the $R A$ was not cytotoxic in low concentrations up to $100 \mu \mathrm{M}$. At $50 \mu \mathrm{M}$ concentration $R A$ promoted cell proliferation and did not cause significant increase in $\mathrm{H}_{2} \mathrm{O}_{2}$ production.
\end{abstract}

\section{Introduction}

In the last few decades there has been increasing interest in the therapeutical application of polyphenolic and antioxidant molecules. These polyphenolic compounds are secondary metabolic products; they play different roles in the lives of the plants $[6,13,9,10]$. The caffeic acid derivative, rosmarinic acid (RA) has an anti-inflammatory [11, 7] and anti-mutagenic [5, 3] effects and it can reduce the cancer $[14,16]$.

The small intestine has absorptive and metabolic capabilities and the intestinal epithelium forms a physical barrier that acts as a defense line against toxins and other pathogens [15].For this reason, integrity of the intestinal epithelial cells is utmost important for maintaining both general health and farm animal yields.

We used a non-transformed porcine intestinal epithelial IPEC-J2 cell line (ACC 701). The cells were isolated from mid-jejunum of a neonatal piglet. It is non-tumorigenic and widely used cell line for modeling and testing the small intestine in vitro [1,12]. The cells can become polarized and form tight junctions.

In our research, we sought to find out how RA affects the cell viability and the TER of IPEC$\mathrm{J} 2$ cells and how the extracellular level of $\mathrm{H}_{2} \mathrm{O}_{2}$ changes in the presence of RA.

\section{Materials and Methods}

\subsection{The maintenance of IPEC-J2 cells and culture conditions}

IPEC-J2 cells were cultured in 50\% Dulbecco's Modified Eagle's Medium (DMEM) and 50\% Ham's F12 Nutrient Mixture (Sigma-Aldrich) containing $1.5 \mathrm{mM}$ HEPES, 5\% fetal bovine serum (Biocenter), 1\% insulin/transferrin/sodium selenite media supplement (Invitrogen), $5 \mathrm{ng} / \mathrm{ml}$ epidermal growth factor (Invitrogen), and 1\% penicillin/streptomycin (Invitrogen).The culture medium was refreshed every other day. IPEC-J2 cells were between passages 42-48. Seeding density for the cells was $1 \times 10^{4}$ cells / well of a 96-well plate (Transwell) to investigate the cytotoxicity with MTS assay. When studying TER and $\mathrm{H}_{2} \mathrm{O}_{2}$ production, the cell-seeding density was $1.5 \times 10^{5}$ cells / well in a 6-well polyester membrane insert containing plates (Transwell,

\footnotetext{
* Corresponding author. Tel.: +36 (1) 478-4100/8569;

E-mail address: Pomothy.Judit.Mercedesz@univet.hu
} 
Sigma-Aldrich, Corning Costar).The insert containing plates had a $1.5 \mathrm{ml}$ apical and $2 \mathrm{ml}$ basolateral volume per well. The treatment was applied in the apical compartment. After $24 \mathrm{~h}$ of treatments, the cell free supernatants were collected for further experiments. The IPEC-J2 cells were incubated at $37^{\circ} \mathrm{C}$ in a humidified atmosphere of $5 \% \mathrm{CO}_{2}$.

\subsection{Treatment with RA}

We tested four RA concentrations in MTS cell viability assay. Cells were treated for $24 \mathrm{~h}$ with the RA at 50,100, 200 and $400 \mu \mathrm{M}$ concentrations. The rosmarinic acid was dissolved in phenol red-free DMEM:F12 culture medium (Lonza) and the solution was filtered $(0.2 \mu \mathrm{m}$, Acrodisc Syringe Filters, Invitrogen) before application on the IPEC-J2 cells. For further experiments RA was used at $50 \mu \mathrm{M}$ concentration and the control samples were treated only with phenol red-free DMEM:F12 culture medium.

\subsection{MTS assay for cell viability}

MTS reagent (CellTiter96Aqueous OneSolution, Promega) is a tetrazolium inner salt which is converted in metabolically active cells to a colored formazan product. This conversion is thought to be carried out by $\mathrm{NAD}(\mathrm{P}) \mathrm{H}$-dependent dehydrogenase enzymes in the mitochondria. After the $24 \mathrm{~h}$ incubation, the cells were washed twice with $1 \%$ PBS before the MTS solution was added. $1.5 \mathrm{~h}$ of incubation, the absorbance was measured at $490 \mathrm{~nm}$ using an ELISA Reader (EZ Read Biochrom 400).

\subsection{TER for membrane integrity strength measurement}

The confluent IPEC-J2 monolayer (above $1 \mathrm{kOhm}$ TER values) was treated with $50 \mu \mathrm{M}$ RA for $24 \mathrm{~h}$. The TER values were measured prior to the treatments $(0 \mathrm{~h})$, then after $18 \mathrm{~h}$ and $24 \mathrm{~h}$ intervals using EVOM Epithelial Tissue Volt/ Ohmmeter (World Precision Instruments, Berlin, Germany). The results were calculated as $\mathrm{k} \Omega \times \mathrm{cm}^{2}$ by multiplying the values by the surface area of the monolayer $\left(4.67 \mathrm{~cm}^{2}\right)$.

\subsection{Amplex Red assay for extracellular $\mathrm{H}_{2} \mathrm{O}_{2}$ detection}

The redox status of the cells was measured by using the Amplex Red Hydrogen Peroxide Assay Kit (Invitrogen, Molecular Probes). With this method we were able to calculate the concentration of $\mathrm{H}_{2} \mathrm{O}_{2}$ from fluorescence intensity. The Amplex Red working solution reacts with $\mathrm{H}_{2} \mathrm{O}_{2}$ in the presence of horseradish peroxidase and producing a highly fluorescent molecule, the resorufin. $50 \mu \mathrm{l}$ of the collected cell free supernatant was mixed with the Amplex Red working solution according to the manufacturer's instructions. The fluorescence intensity was measured at $590 \mathrm{~nm}$ with a fluorimeter (Victor X2 2030, Perkin Elmer, Waltham, MA, USA).

\subsection{Statistical analysis}

All data are expressed as means \pm standard deviations. The statistical analysis of the results was performed by using the R Core Team (2016). R: A language and environment for statistical computing (R Foundation for Statistical Computing, Vienna, Austria). The data were analyzed by one-way ANOVA coupled with the post hoc Tukey test. $p$ values $<0.05$ were considered to be statistically significant $\left({ }^{*} p<0.05 ;{ }^{* *} p<0.01 ;{ }^{* * *} p<0.001\right)$.

\section{Results}

\subsection{The effect of RA on the viability of IPEC-J2 cell}

The MTS cell viability test, which measures the mitochondrial metabolic activity, has been used as an indirect evaluation of viability of IPEC-J2 cells exposed to RA at 50, 100, 200, $400 \mu \mathrm{M}$ concentrations. A significant increase in cell viability was observed upon a $24 \mathrm{~h}$ exposure of proliferating IPEC-J2 cells to $50 \mu \mathrm{M}$ RA (Figure 1). Exposure of cells to RA at 200 and $400 \mu \mathrm{M}$ concentrations resulted in significantly decreased absorbance values. 


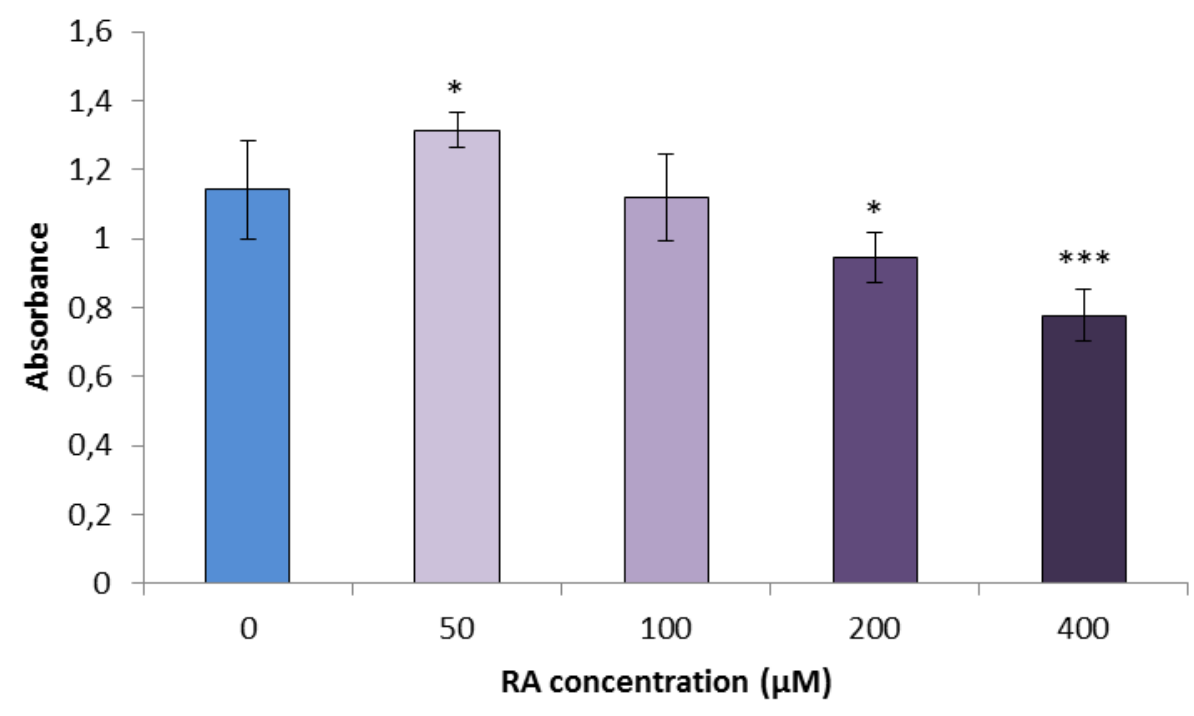

Figure 1.The effect of RA on the viability of IPEC-J2 cells. Cells were exposed to RA at 50, 100, 200 and $400 \mu M$ concentrations and the MTS cell viability test was used. Results are representative data of five independent experiments. ${ }^{*}$ indicates a significant difference compared to the control ( $\left.{ }^{*} p<0.05 ;{ }^{* * *} p<0.001\right)$.

\subsection{The effect of $50 \mu \mathrm{M}$ RA on the membrane integrity of IPEC-J2 cells}

TER was measured to elucidate the functional integrity of the epithelial cell monolayer. When IPEC-J2 cells were treated with $50 \mu \mathrm{M}$ RA, the TER values significantly increased at the end of the $24 \mathrm{~h}$ incubation time (Figure 2). However, there was no significant effect of RA on IPEC-J2 cells within $18 \mathrm{~h}$ after the starting of the treatment.

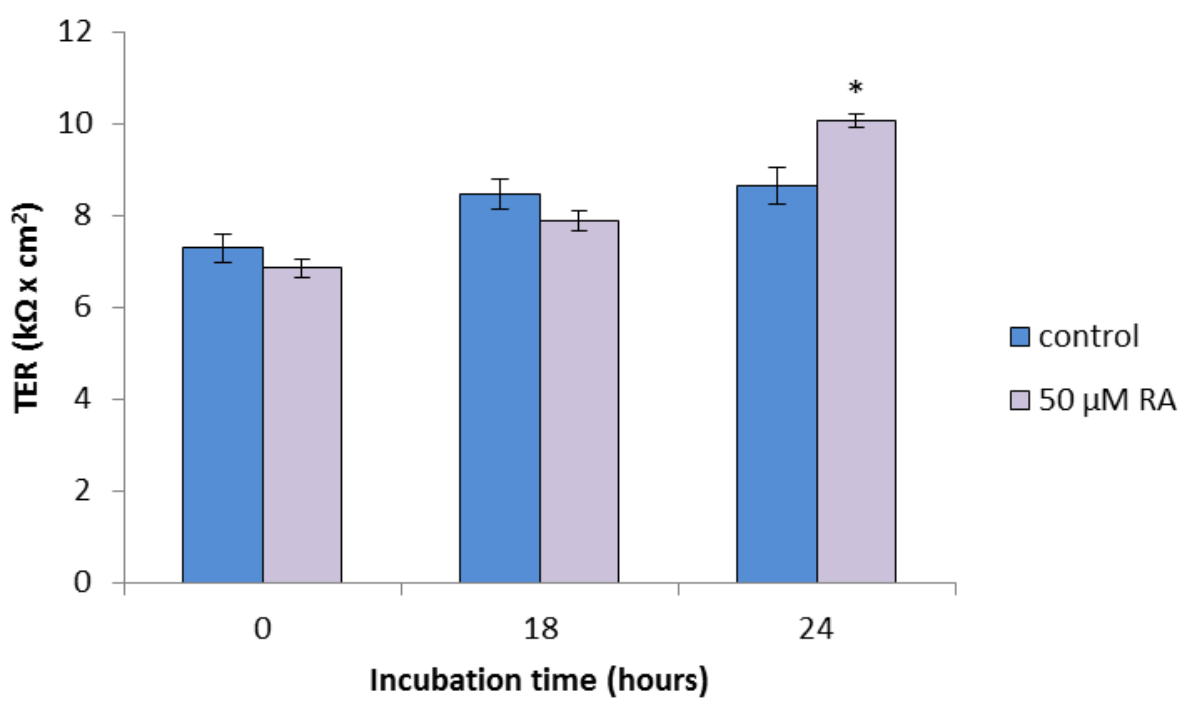

Figure 2.Effect of RA on the cell monolayer integrity of IPEC-J2 cells. Cells were exposed to RA at $50 \mu \mathrm{M}$ for $24 \mathrm{~h}$. After $24 \mathrm{~h}$ incubation the treated cells show significantly higher TER values.

Results are representative data of three independent experiments. *indicates a significant difference as compared to the control $\left({ }^{*} p<0.05\right)$.

\subsection{The effect of RA on the extracellular $\mathrm{H}_{2} \mathrm{O}_{2}$ production of IPEC-J2 cell}

The extracellular $\mathrm{H}_{2} \mathrm{O}_{2}$ is a marker of the oxidative stress. Amplex Red assay was used to measure the changes of the extracellular $\mathrm{H}_{2} \mathrm{O}_{2}$ levels in cell free supernatants. Fluorescence 
intensities were measured after $24 \mathrm{~h}$ of incubation with $50 \mu \mathrm{M}$ RA (Figure 3). It was found that 50 $\mu \mathrm{M}$ RA did not cause significant elevation in $\mathrm{H}_{2} \mathrm{O}_{2}$ levels.

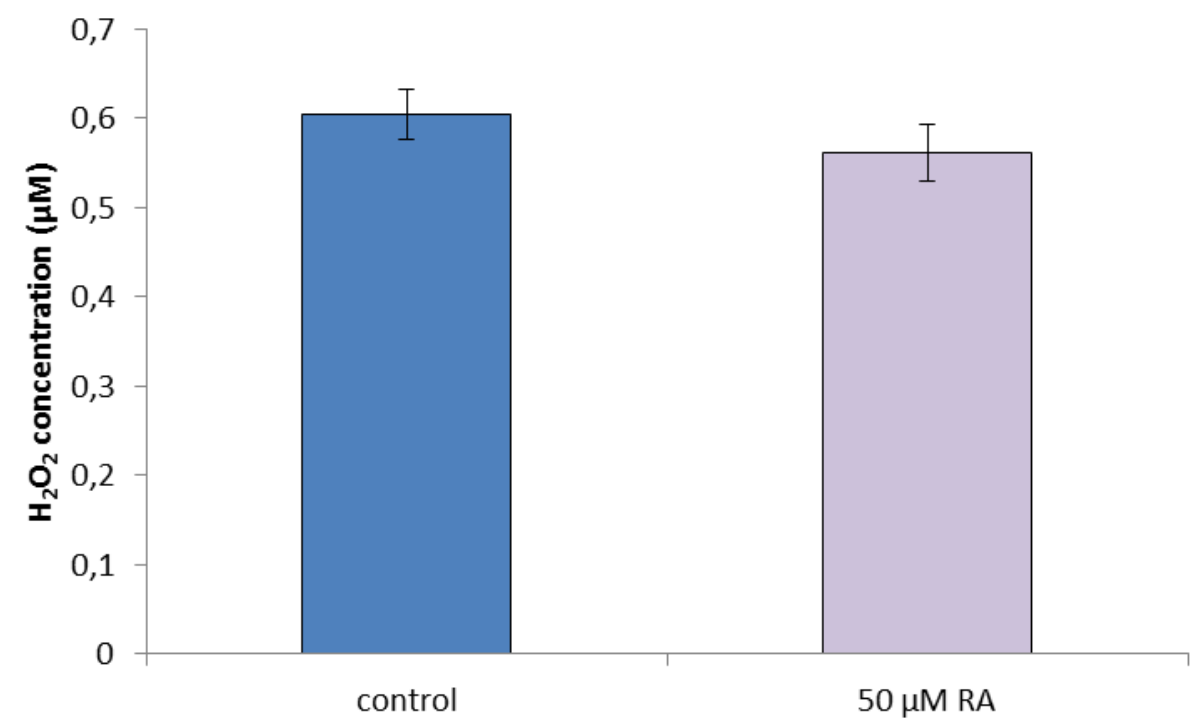

Figure 3. The effect of $\mathrm{RA}$ on $\mathrm{H}_{2} \mathrm{O}_{2}$ production of IPEC-J2 cells. Cells were exposed to $\mathrm{RA}$ at $50 \mu M$ for $24 \mathrm{~h}$. To detect the changes in $\mathrm{H}_{2} \mathrm{O}_{2}$ production Amplex Red assay was used. No significant differences were found ( $p>0.05$ ) between the control and the RA treated groups. Results are representative values of three independent experiments.

\section{Discussion}

The IPEC-J2 cell line is a good model system to study the impact of supplementation of piglet feed with dietary antioxidants [8]. The beneficial effect of RA on porcine cell survival can be related to its specific structure [4].This molecule possess two aromatic rings and double bonds that increase the efficacy of receiving electrons through resonance in order to stabilize free radicals after donating a proton to the ROS [2].

The results in this study demonstrated that moderate to low concentrations of RA improved cell viability. However, high concentrations of RA (above $200 \mu \mathrm{M}$ ) caused cell death to great extent. It was demonstrated that $50 \mu \mathrm{M}$ RA significantly improved the integrity of the IPEC-J2 cell monolayer after $24 \mathrm{~h}$ incubation and did not cause significant changes in the extracellular $\mathrm{H}_{2} \mathrm{O}_{2}$ production.

\section{Conclusion}

In conclusion, at $50 \mu \mathrm{M}$ RA has the capacity to increase cell viability and the membrane integrity while it does not cause significant enhancement in extracellular $\mathrm{H}_{2} \mathrm{O}_{2}$ level. Application of low concentration of RA seems to be an effective way to strengthen epithelial barrier integrity. However, further in vivo studies are needed for confirming in vitro observed beneficial effects of RA is to establish daily application schedule of RA as porcine feed additive in the future.

\section{Acknowledgment}

The Project is supported by the European Union and co-financed by the European Social Fund (grant agreement no. EFOP-3.6.1-16-2016-00024, EFOP-3.6.2-16-2017-00012). This project was supported by the János Bolyai Research Scholarship of the Hungarian Academy of Sciences. This research was supported by the Hungarian Scientific Research Fund [grant numbers: 115685 and 124522]. 


\section{References}

[1] A. Cencic and T. Langerholc, "Functional cell models of the gut and their applications in food microbiology - a review," Int. J. Food Microbiol.,vol. 141 Suppl 1, pp. S4-14, Jul. 2010.

[2] S. J. Flora, "Structural, chemical and biological aspects of antioxidants for strategies against metal and metalloid exposure," Oxid. Med. Cell Longev., vol. 2, no. 4, pp. 191-206, 2009.

[3] M. A. Furtado, L. C. F. de Almeida, R. A. Furtado, W. R. Cunha, and D. C. Tavares, "Antimutagenicity of rosmarinic acid in Swiss mice evaluated by the micronucleus assay," Mutat. Res.,vol. 657, no. 2, pp. 150-154, 2008.

[4] L. P. Gao, H. L. Wei, H. S. Zhao, S. Y. Xiao, and R. L. Zheng, "Antiapoptotic and antioxidant effects of rosmarinic acid in astrocytes," Pharmazie, vol. 60, no. 1, pp. 62-65, 2005.

[5] M. Gulluce, D. Yanmis, F. Orhan, T. Bal, M. Karadayi, and F. Sahin, "Determination of antimutagenic properties of Rosmarinic acid, a phenolic compound isolated from Mentha longifolia ssp. longifolia with yeast DEL assay," in Microbes in Applied Research, 0 vols., WORLD SCIENTIFIC, 2012, pp. 526-530.

[6] C. W. I. Haminiuk, G. M. Maciel, M. S. V. Plata-Oviedo, and R. M. Peralta, "Phenolic compounds in fruits - an overview," International Journal of Food Science \& Technology, vol. 47, no. 10, pp. 2023-2044, 2012.

[7] N. Huang, C. Hauck, M. Y. Yum, L. Rizshsky, M. P. Widrlechner, J. A. McCoy, P. A. Murphy, P. M. Dixon, B. J. Nikolau and D. F. Birt, "Rosmarinic acid in Prunella vulgaris ethanol extract inhibits lipopolysaccharide-induced prostaglandin E2 and nitricoxide in RAW 264.7 mouse macrophages," J. Agric. Food Chem.,vol. 57, no. 22, pp. 10579-10589, 2009.

[8] X. Ma, P. X. Fan, L. S. Li, S. Y. Qiao, G. L. Zhang, and D. F. Li, "Butyrate promotes the recovering of intestinal wound healing through its positive effect on the tight junctions," J. Anim. Sci.,vol. 90 Suppl 4, pp. 266-268, 2012.

[9] C. Manach, A. Scalbert, C. Morand, C. Rémésy, and L. Jiménez, "Polyphenols: food sources and bioavailability," Am. J. Clin. Nutr.,vol. 79, no. 5, pp. 727-747, May 2004.

[10] P. G. Pietta, "Flavonoids as antioxidants," J. Nat. Prod.,vol. 63, no. 7, pp. 1035-1042, Jul. 2000.

[11] J. Rocha, M. Eduardo-Figueira, A. Barateiro, A. Fernandes, D. Brites, R. Bronze, C. M. Duarte, A. T. Serra, R. Pinto, M. Freitas, E. Fernandes, B. Silva-Lima, H. Mota-Filipe and B. Sepodes , "Anti-inflammatory effect of rosmarinic acid and an extract of Rosmarinus officinalis in rat models of local and systemic inflammation," Basic Clin. Pharmacol. Toxicol.,vol. 116, no. 5, pp. 398-413, May 2015.

[12] P. Schierack, M. Nordhoff, M. Pollmann, K. D. Weyrauch, S. Amasheh, U. Lodemann, J. Jores, B. Tachu, S. Kleta, A. Blikslager, K. Tedin and L. H. Wieler, "Characterization of a porcine intestinal epithelial cell line for in vitro studies of microbial pathogenesis in swine," Histochem. Cell Biol.,vol. 125, no. 3, pp. 293-305, Mar. 2006.

[13] E. G. W. M. Schijlen, C. H. Ric de Vos, A. J. van Tunen, and A. G. Bovy, "Modification of flavonoid biosynthesis in crop plants," Phytochemistry, vol. 65, no. 19, pp. 2631-2648, Oct. 2004.

[14] M. K. Swamy, U. R. Sinniah, and A. Ghasemzadeh, "Anticancer potential of rosmarinic acid and its improved production through biotechnological interventions and functional genomics," Appl. Microbiol. Biotechnol.,vol. 102, no. 18, pp. 7775-7793, Sep. 2018.

[15] K. Zhang, M. W. Hornef, and A. Dupont, "The intestinal epithelium as guardian of gut barrier integrity," Cell. Microbiol.,vol. 17, no. 11, pp. 1561-1569, 2015.

[16] Y. Zhang, M. Hu, L. Liu, X. L. Cheng, J. Cai, J. Zhou and T. Wang, "Anticancer effects of Rosmarinic acidin OVCAR-3 ovarian cancer cells are mediated via induction of apoptosis, suppression of cell migration and modulation of IncRNA MALAT-1 expression," J BUON, vol. 23, no. 3, pp. 763-768, Jun. 2018. 